\title{
Monitoring of Atmospheric Pollutant Concentrations in the City of Dakar, Senegal
}

\author{
Baïdy Sow ${ }^{1 *}$, Bertrand Tchanche ${ }^{1}$, Ibrahima Fall1, Saliou Souaré2, Aminata Mbow-Diokhané ${ }^{2}$ \\ ${ }^{1}$ Department of Physics, Alioune Diop University, Bambey, Senegal \\ ${ }^{2}$ Centre de Gestion de la Qualité de l'Air (CGQA), Dakar, Senegal \\ Email: ^baidy.sow@uadb.edu.sn
}

How to cite this paper: Sow, B., Tchanche, B,, Fall, I., Souaré, S. and Mbow-Diokhané, A. (2021) Monitoring of Atmospheric Pollutant Concentrations in the City of Dakar, Senegal. Open Journal of Air Pollution, 10, $18-30$.

https://doi.org/10.4236/ojap.2021.101002

Received: January 22, 2021

Accepted: March 26, 2021

Published: March 29, 2021

Copyright $\odot 2021$ by author(s) and Scientific Research Publishing Inc. This work is licensed under the Creative Commons Attribution International License (CC BY 4.0).

http://creativecommons.org/licenses/by/4.0/

(c) (i) Open Access

\begin{abstract}
The lack of data on air quality monitoring and neglected and overlooked pollutant emissions in the transportation and industrial sectors are motives for the government of Senegal to set up, in 2009, an air quality management center, the CGQA (Centre de Gestion de la Qualité de l'Air). Air quality monitoring at CGQA deals with mainly six pollutants: carbon monoxide (CO), nitrogen oxides $\left(\mathrm{NO}_{\mathrm{x}}\right)$ (with nitrogen dioxide $\left(\mathrm{NO}_{2}\right)$ and nitrogen monoxide (NO)), sulfur dioxide $\left(\mathrm{SO}_{2}\right)$, ground-level ozone $\left(\mathrm{O}_{3}\right)$, Benzene-Toluene-Xylenes (BTX), and particulate matters (PM) with diameters less than $10 \mu \mathrm{m}\left(\mathrm{PM}_{10}\right)$ and $2.5 \mu \mathrm{m}\left(\mathrm{PM}_{2.5}\right)$. The concentration levels of gaseous pollutants $\left(\mathrm{CO}, \mathrm{O}_{3}\right.$, $\mathrm{NO}_{2}$ and $\mathrm{SO}_{2}$ ) in the city generally remain below the limit value set by the WHO (World Health Organization). However, particulate matters ( $\mathrm{PM}_{10}$ and $\mathrm{PM}_{2.5}$ ) are the most important pollutants observed in Dakar, they far exceed the annual thresholds set by the WHO and the national standard (NS 05-062). This situation results in an Air Quality Index (AQI) around bad and very bad during the dry season (November to May) and good to moderate during the rainy season (June to October). The concentrations of $\mathrm{PM}_{10}$ and $\mathrm{PM}_{2.5}$ vary respectively from 120 to $180 \mu \mathrm{g} \cdot \mathrm{m}^{-3}$ and from 25 to $48 \mu \mathrm{g} \cdot \mathrm{m}^{-3}$. The average concentrations of pollutants therefore vary from one area to another and depending on the location of the air quality monitoring station (near industrial sites, traffic, etc.).
\end{abstract}

\section{Keywords}

Air Quality, Emission, Health, Monitoring, Particulate Matter, Pollutants, Standard

\section{Introduction}

Atmospheric air pollution is a complex phenomenon with variety of origins and 
sources. In urban areas, it is caused mainly by mobile combustion in transportation vehicles which burn large quantities of fossil fuels. The city of Dakar, is home to more than four (4) million inhabitants, nearly a quarter of the population of Senegal. It has one of the highest urbanization rates in Africa, and is therefore particularly faces growing transport demand. The demographic growth is due to several factors: natural births, migration from other cities and rural areas as well, and the concentration of infrastructure and improved services and economic attractiveness. Dakar holds $80 \%$ of the country's economic and industrial activities. Road transport is the main mode of transport in Senegal [1], and faces many challenges: poor maintenance, lack of infrastructure, mismanagement, etc. Dakar's car fleet represents $73 \%$ of the national vehicle fleet, and the consequence is intense road traffic and congestions. According to studies carried out by Tchanche (AIMS, COAE, Earth), road vehicles use oil products (gasoline and diesel oil) and are distributed as follows: gasoline (38\%) and diesel (59\%) [2]. Transport sector represents $30 \%$ of total energy consumed in the country and is second after the residential sector [3]. Transport sector is dominated by road transport which consumes $95 \%$ of total energy consumed and distributed between diesel (80\%) and gasoline (20\%) [4]. In addition, the industrial sector depends more than $70 \%$ on fossil fuels [3]. The consequence of the utilization of these fossil fuels is, among other things, an obvious deterioration in air quality.

The first study on air pollution in Dakar was carried out by The World Bank in the framework of its initiative on air quality in sub-Sahara Africa in 1998. That study was based on simulation of the traffic in the city of Dakar. Since then, a study financed by the Nordic Development Fund (FND) has made it possible to obtain more precise data on the basis of a sampling and analysis program during two assessment campaigns carried out by the Norwegian Institute of Air Research (NILU) [5]. This study allowed Senegal to have standard values for $\mathrm{NO}_{2}, \mathrm{SO}_{2}, \mathrm{O}_{3}, \mathrm{VOC}, \mathrm{PM}_{10}$ and $\mathrm{PM}_{2.5}$ [6]. There is some research work on air pollution in Dakar that can be cited [7]-[14] but more is still needed.

In 2009, with the support of The World Bank, the Senegalese government has set up an air quality management center, the CGQA (Centre de Gestion de la Qualite de l'Air) with as mission the monitoring of the air quality in the city of Dakar. Several measurement stations, six in total have been installed so far: Cathedrale, Yoff and a new one is to be installed in the upcoming year in Guediawaye. Pollutants monitored are particle matters (PM): $\mathrm{PM}_{10}, \mathrm{PM}_{2.5}$, and atmospheric gases: $\mathrm{O}_{3}, \mathrm{CO}, \mathrm{SO}_{2}, \mathrm{NO}_{2}$ and $\mathrm{BTX}$. An air quality index (AQI) is calculated on daily basis to establish the concentration of pollutants and has become an important means to characterize the pollution and helps to send warnings in case of critical air quality degradation. This study is collaboration between the CGQA and the Alioune Diop University in which a focus is given to the air quality monitoring. The air quality monitoring system is presented along with the regulation framework on air pollution and recorded IQA is discussed. 


\section{Materials and Methods}

\subsection{Air Quality Management Center (CGQA)}

Dakar has a network of 6 fixed stations, 5 in the inner-city and one in one of its suburbs (Guediawaye) (Figure 1). In addition, the CGQA has a mobile station called a "laboratory truck" which is part of the air quality monitoring system. In the inner-city, the stations are scattered in several activity zones, first the Yoff-Station near the old Dakar airport. This station is defined as a station measuring background pollution. It corresponds to pollution levels, far from traffic, representative of the general atmosphere of an entire geographic area. This is minimum pollution to which the population of this sector is subjected, whatever their activity, and for long periods. Background pollution is measured in places far from any direct source of pollution. The Bel-Air-Station is an industrial type of station located in the port area, the HLM-Station in the inner suburbs is a per-urban type of station. The Republic-Station (also called the Cathedral) in the center of the city is installed on one side of a boulevard with intense automobile traffic. Finally, the Medina-Station, also on a roadside, is in a suburban district. These last two stations correspond to so-called road traffic type stations. Unlike background pollution, pollution measured near traffic corresponds to the highest levels to which the population (drivers, cyclists, and pedestrians) is subjected, but over much shorter periods. The measurements are taken on the sidewalk, as close as possible to automobile traffic. These levels are representative of the location where the measurement was taken (grand boulevard, motorway, ring road, etc.) and can therefore vary greatly from one traffic site to another.

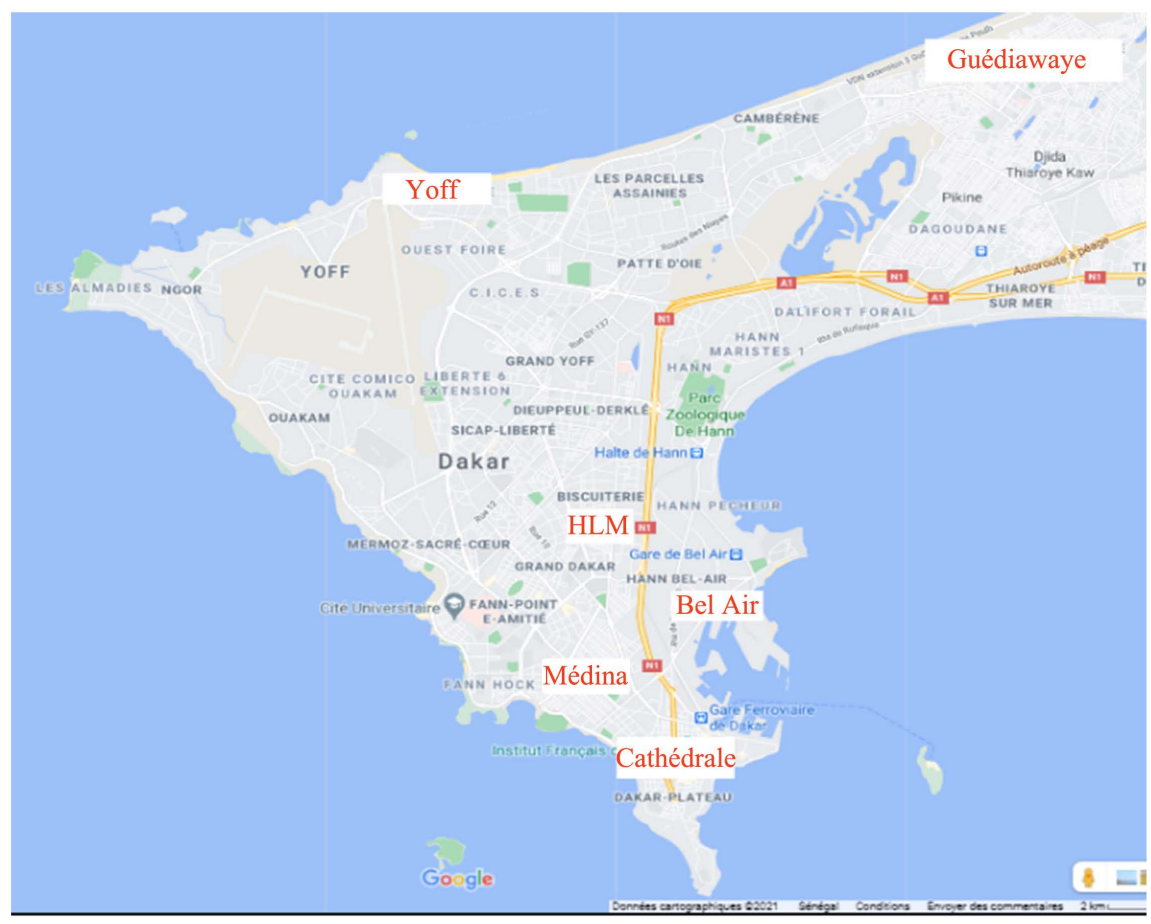

Figure 1. Location of air quality measurement stations in Dakar. 
The CGQA's monitoring work mainly concerns the pollutants, which are very harmful to health: $\mathrm{PM}_{10}, \mathrm{PM}_{2.5}, \mathrm{O}_{3}, \mathrm{CO}, \mathrm{SO}_{2}, \mathrm{NO}_{2}$ and BTX. However $\mathrm{NO}_{2}$ and $\mathrm{PM}_{10}$ are measured at all stations (Table 1). The other pollutants are measured according to the geographical location and the characteristics of the area.

\subsection{Senegalese Regulations on Air Pollution}

Law $\mathrm{N}^{\circ}$ 2001-01 of January 15, 2001 concerns the principle of the right of everyone to breathe air that does not harm their health. This law incorporates for the first time a standard (Senegalese Standard NS 05-060) which sets the requirements on gas emissions and exhaust fumes from motor vehicles. This standard only applies to carbon monoxide (CO), hydrocarbons (HC) and smoke opacity. Afterward in November 2003, the government set the conditions for the application of the new standard NS 05-062 on atmospheric pollution and to regulate the terms for reject of atmospheric pollutants into the ambient air [6]. It applies generally to existing and new stationary installations and to vehicles that generate gaseous effluents.

The WHO air quality guidelines are part of actions that encourage states in the fight against air pollution and its deleterious effects on human health. They are used according to the Senegalese context as references in environmental protection policies. Table 2 presents a summary of the limit values of the Senegalese regulations (NS-05-062) compared to the guidelines of the World Health Organization (WHO) on air quality.

According to the WHO, national air quality standards are set by each state taking into account health risks, technological feasibility, economic considerations and various other political and social factors which, in turn, will depend on, among other things, the degree of development and national capacity in air quality management [15].

\subsection{Air Quality Index (AQI)}

$$
\mathrm{AQI}=\frac{\text { Pollutant concentration }}{\text { Limit value }} \times 100
$$

Table 1. The pollutants measured by the different stations (Source: CGQA).

\begin{tabular}{cccccccc}
\hline \multirow{2}{*}{ Station Names } & \multicolumn{7}{c}{ Measured pollutants } \\
\cline { 2 - 7 } & $\mathrm{SO}_{2}$ & $\mathrm{NO}_{2}$ & $\mathrm{O}_{3}$ & $\mathrm{CO}$ & $\mathrm{PM}_{10}$ & $\mathrm{PM}_{2.5}$ & $\mathrm{BTX}$ \\
\hline Cathedrale & $\mathrm{x}$ & $\mathrm{x}$ & $\mathrm{x}$ & $\mathrm{x}$ & $\mathrm{x}$ & $\mathrm{x}$ & \\
Medina & & $\mathrm{x}$ & & $\mathrm{x}$ & $\mathrm{x}$ & & \\
HLM & $\mathrm{x}$ & $\mathrm{x}$ & $\mathrm{x}$ & & $\mathrm{x}$ & & \\
Bel Air & $\mathrm{x}$ & $\mathrm{x}$ & & & $\mathrm{x}$ & $\mathrm{x}$ & $\mathrm{x}$ \\
Yoff & & $\mathrm{x}$ & $\mathrm{x}$ & & $\mathrm{x}$ & & \\
Guediawaye & $\mathrm{x}$ & $\mathrm{x}$ & $\mathrm{x}$ & $\mathrm{x}$ & $\mathrm{x}$ & $\mathrm{x}$ & \\
\hline
\end{tabular}

$\mathrm{x}$ represents the pollutant measured by each station. 
Table 2. Air quality limit values for Senegal and WHO (Source: CGQA).

\begin{tabular}{|c|c|c|c|c|}
\hline \multirow{2}{*}{ Pollutants } & \multirow{2}{*}{ Time average } & \multicolumn{3}{|c|}{ Limit Values $\left(\mathrm{en} \cdot \mu \mathrm{g} \cdot \mathrm{m}^{-3}\right.$ ) } \\
\hline & & WHO guidelines & NS-05-062 (2003) & NS-05-062 (2019) \\
\hline \multirow{2}{*}{$\mathrm{SO}_{2}$} & 10 minutes & 500 & - & 500 \\
\hline & Daily & 20 & 125 & 50 \\
\hline \multirow{2}{*}{$\mathrm{NO}_{2}$} & 1 Hour & 200 & 200 & 200 \\
\hline & Annual & 40 & 40 & 40 \\
\hline $\mathrm{O}_{3}$ & 8 Hours & 100 & 120 & 100 \\
\hline \multirow{2}{*}{$\mathrm{CO}$} & 1 Hour & 30,000 & - & 30,000 \\
\hline & 8 Hours & 10,000 & $30,000(24 \mathrm{~h})$ & 10,000 \\
\hline \multirow{2}{*}{$\mathrm{PM}_{10}$} & Daily & 50 & 260 & 150 \\
\hline & Annual & 20 & 80 & 40 \\
\hline \multirow{2}{*}{$\mathrm{PM}_{2.5}$} & Daily & 25 & - & 75 \\
\hline & Annual & 10 & - & 25 \\
\hline Lead $(\mathrm{Pb})$ & Annual & $0.5-1.0$ & 2 & 0.5 \\
\hline
\end{tabular}

A global air quality index is calculated daily to assess the level of air pollution in Dakar. It corresponds to the average of the AQI of the six pollutants $\left(\mathrm{NO}_{2}\right.$, $\mathrm{SO}_{2}, \mathrm{O}_{3}, \mathrm{CO}, \mathrm{PM}_{10}$ and $\mathrm{PM}_{2.5}$ ) of the six stations. The limit values used to calculate the indices are those of the Senegalese standard and/or the World Health Organization (WHO).

The air quality index (AQI) is scaled between 0 and 500. The higher the index, the more dangerous it represents to public health. When the pollution level is less than or equal to 50, the quality is said to be good and does not present any health risks. On the other hand, an index greater than or equal to 100 poses health risks and when the 200 mark is crossed, a health alert is launched. In such cases each individual can experience serious health effects. A general alert, accompanied by emergency measures, is required when the index goes above 300 .

\section{Results and Discussions}

Figure 2 represents the change in the daily air quality index (AQI) from 2010 to 2018. It shows the seasonality of pollution episodes with peaks observed between November and April. The air quality remains in the interval bad to very bad. This period corresponds to the dry season with a dominance of the continental trade winds (Harmattan). During the rainy season from June to October the air quality is generally in the interval good to moderate. This is linked to the phenomenon of leaching of pollutants.

Figure 3 and Figure 4 represent the average monthly levels of $\mathrm{PM}_{10}$ and $\mathrm{PM}_{2.5}$ concentrations from 2010 to 2018, respectively. There is seasonality in the concentration of pollutants. These concentrations are higher during the dry season from November to May. The weakest values are recorded during the rainy season from June to October. 


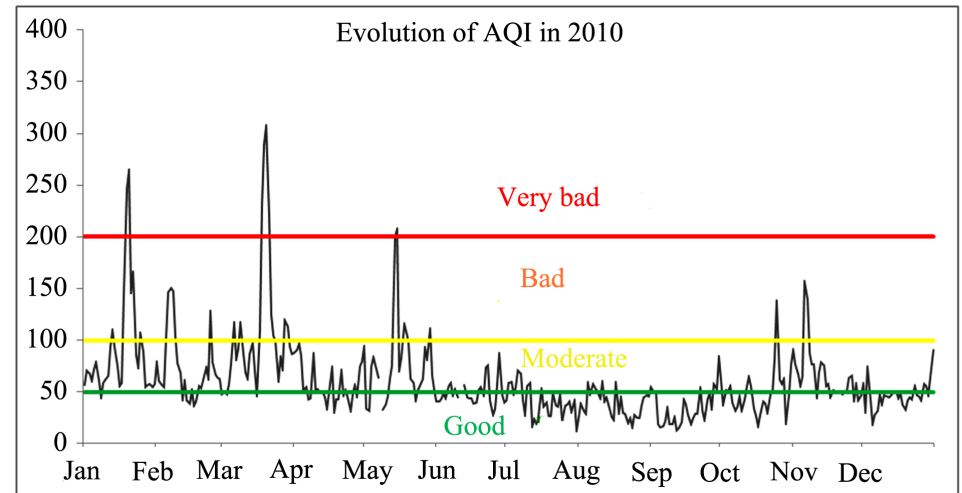

(a)

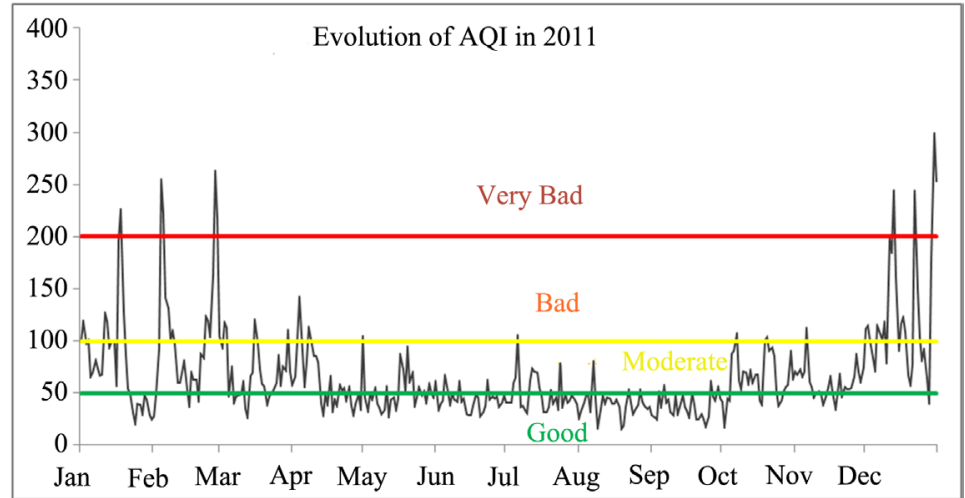

(b)

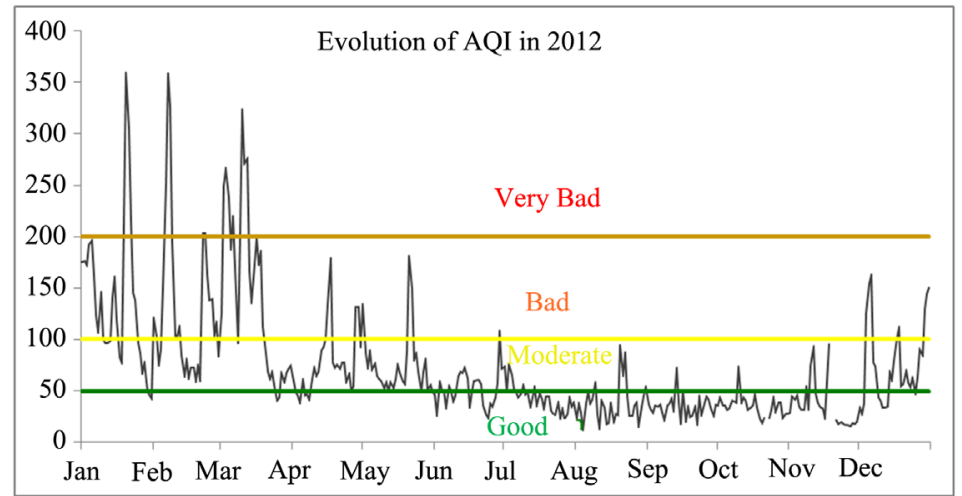

(c)

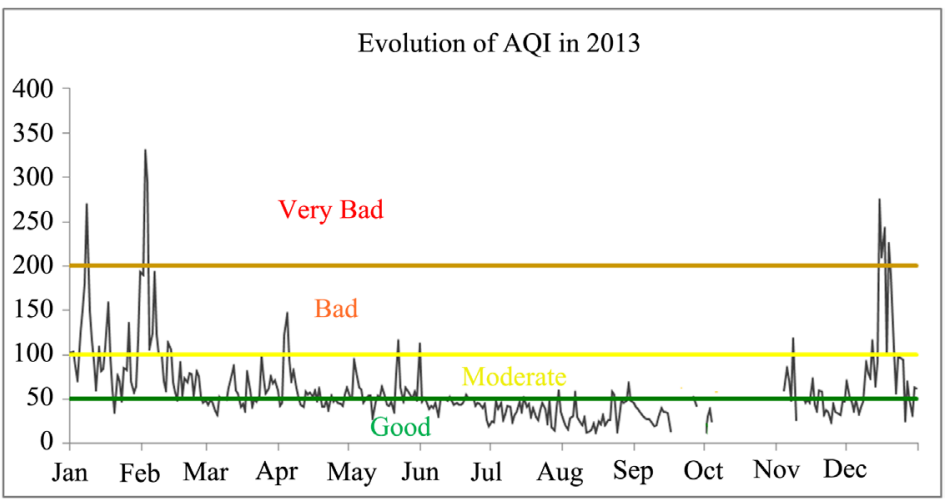

(d) 


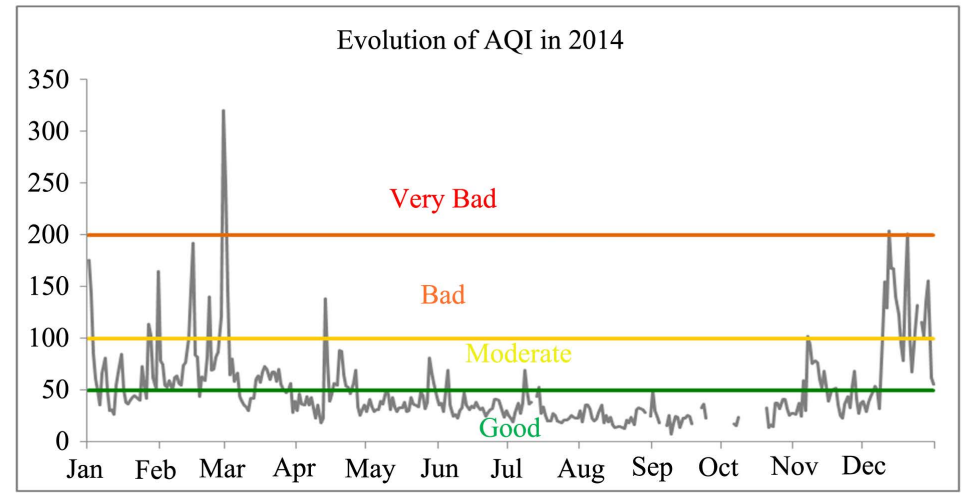

(e)

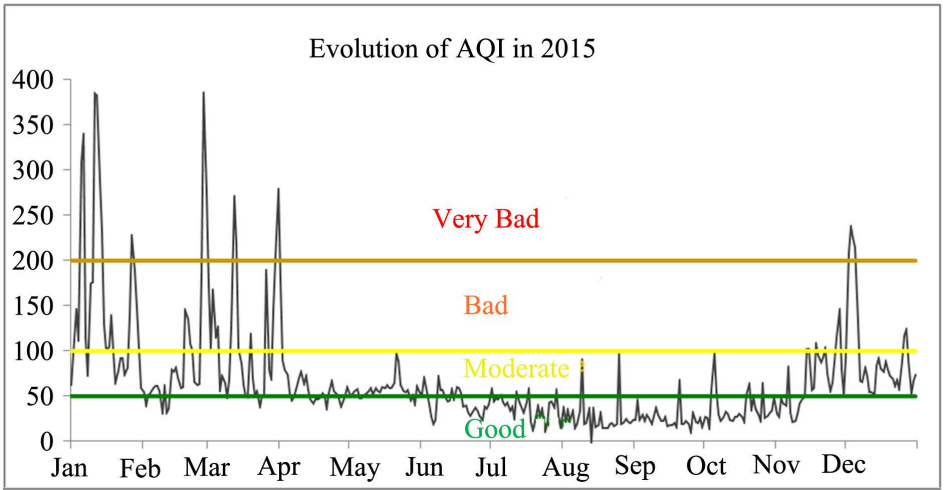

(f)

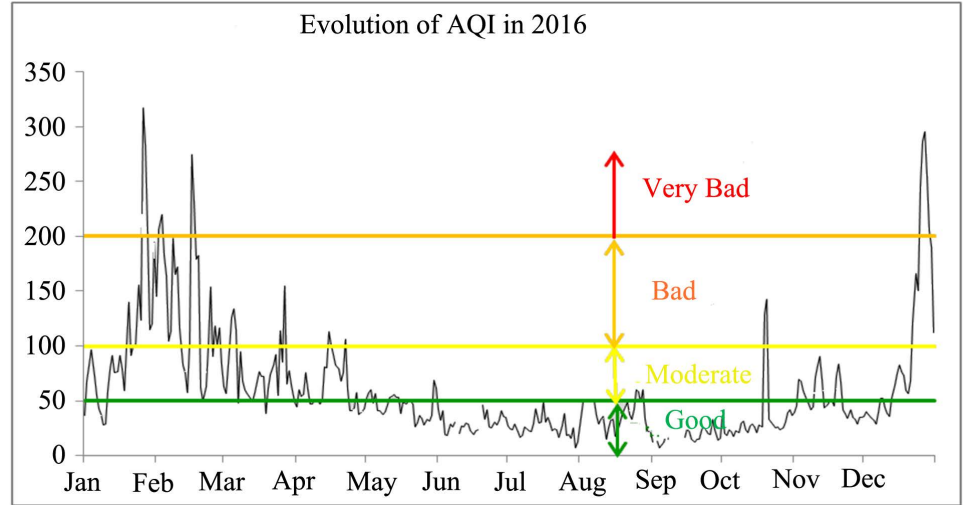

(g)

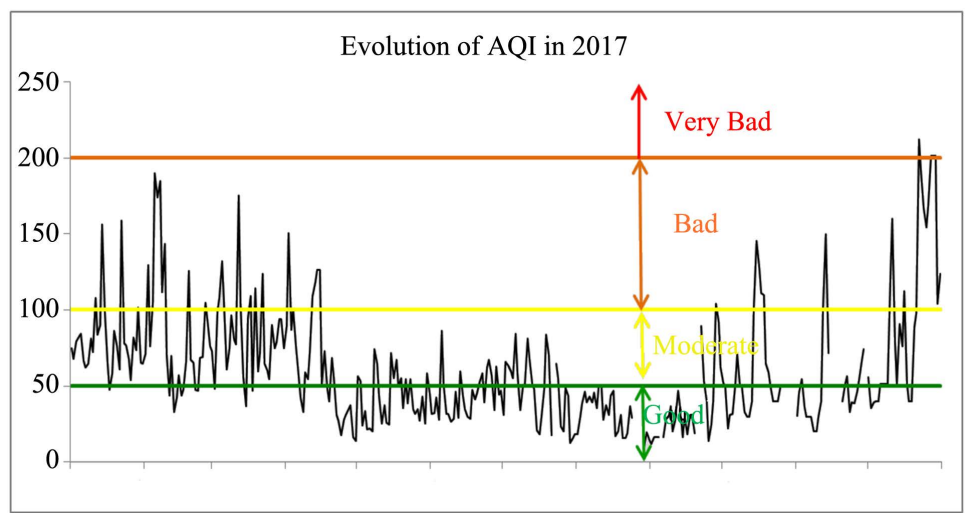

(h) 


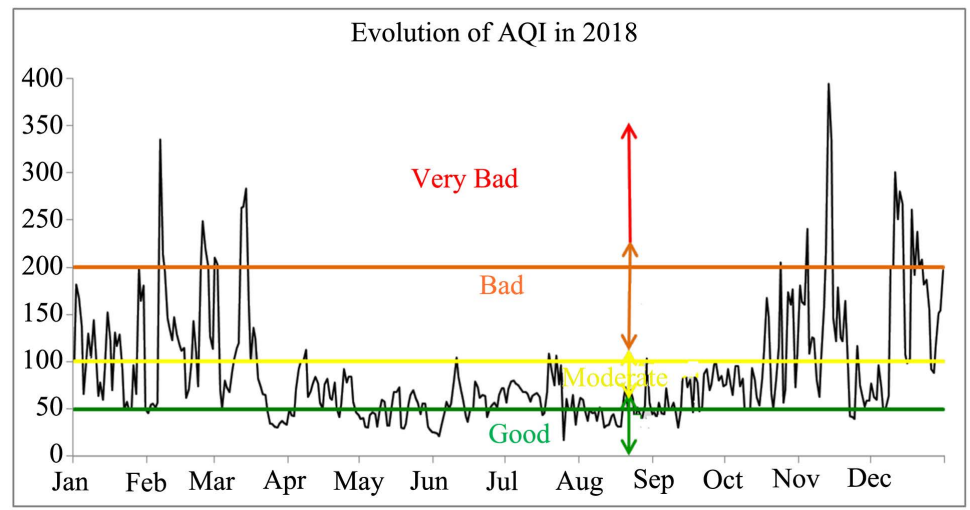

(i)

Figure 2. Evolution of the air quality index (AQI) over the period from 2010 to 2018 (Source: CGQA). (a) AQI 2010; (b) AQI 2011; (c) AQI 2012; (d) AQI 2013; (e) AQI 2014; (f) AQI 2015; (g) AQI 2016; (h) AQI 2017; (i) AQI 2018.

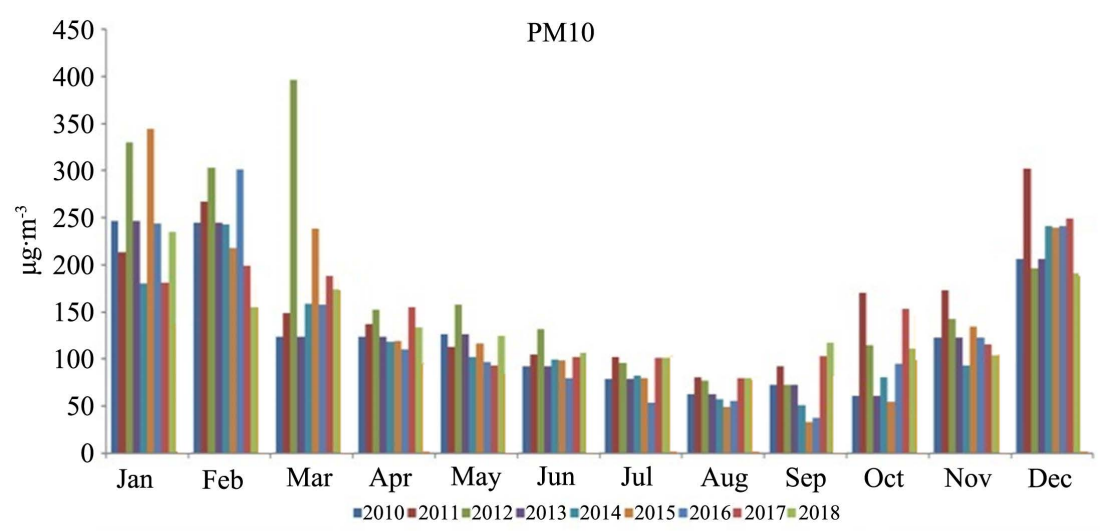

Figure 3. Monthly averages of $\mathrm{PM}_{10}$ concentrations over the period from 2010 to 2018 (Source: CGQA).

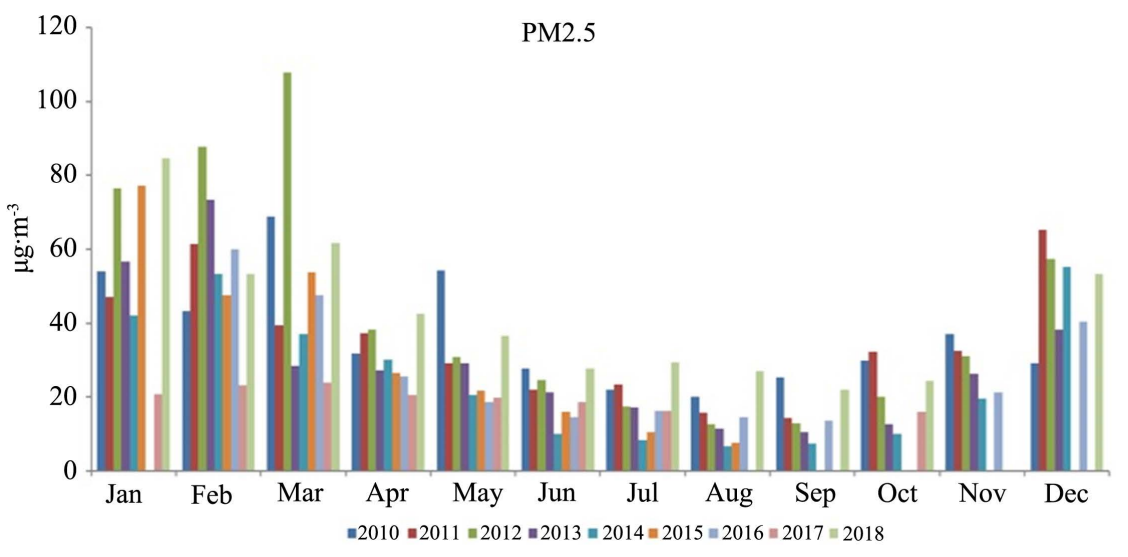

Figure 4. Monthly averages of $\mathrm{PM}_{2.5}$ concentrations over the period from 2010 to 2018 (Source: CGQA).

However, the variation in concentrations differs from month to month and from year to year (Figure 3 and Figure 4). During the dry season the concentrations of $\mathrm{PM}_{10}$ varied between 75 and $380 \mu \mathrm{g} \cdot \mathrm{m}^{-3}$ while the concentrations of 
$\mathrm{PM}_{2.5}$ were between 22 and $110 \mu \mathrm{g} \cdot \mathrm{m}^{-3}$. However, during the rainy season, the concentrations of $\mathrm{PM}_{10}$ and $\mathrm{PM}_{2.5}$ were between 25 and $160 \mu \mathrm{g} \cdot \mathrm{m}^{-3}$ and between 5 and $35 \mu \mathrm{g} \cdot \mathrm{m}^{-3}$, respectively. In addition, it should be noted that 2012 seems to be the most polluted year, with pollution peaks 8 times greater than WHO guidelines for $\mathrm{PM}_{10}$. The high concentrations of $\mathrm{PM}_{10}$ observed during the dry season in the Sahel are due to the transport of dust from the Sahara [16]. The high concentrations of $\mathrm{PM}_{10}$ observed at the start of the rainy season (June-July) would be due to high surface winds produced by the passage of mesoscale convective systems. These winds accompanied by strong dust emissions are generally responsible for the rain in the Sahel. The relatively low concentrations of particles during the rainy season can be linked to the irrigation by rainwater which limits dust emissions. The concentrations are closer to this standard limit in the rainy season. The observed concentration levels largely exceed the guidelines advised by the WHO $\left(20 \mu \mathrm{g} \cdot \mathrm{m}^{-3}\right.$ and $10 \mu \mathrm{g} \cdot \mathrm{m}^{-3}$ respectively for $\mathrm{PM}_{10}$ and $\left.\mathrm{PM}_{2.5}\right)$ with a factor of 6 to $9\left(\mathrm{PM}_{10}\right)$ and a factor of 2 to $5\left(\mathrm{PM}_{2.5}\right)$ and the Senegalese standard NS $05-062\left(40 \mu \mathrm{g} \cdot \mathrm{m}^{-3}\right.$ and $25 \mu \mathrm{g} \cdot \mathrm{m}^{-3}$ respectively for $\mathrm{PM}_{10}$ and $\mathrm{PM}_{2.5}$ ) (Figure 5 and Figure 6).

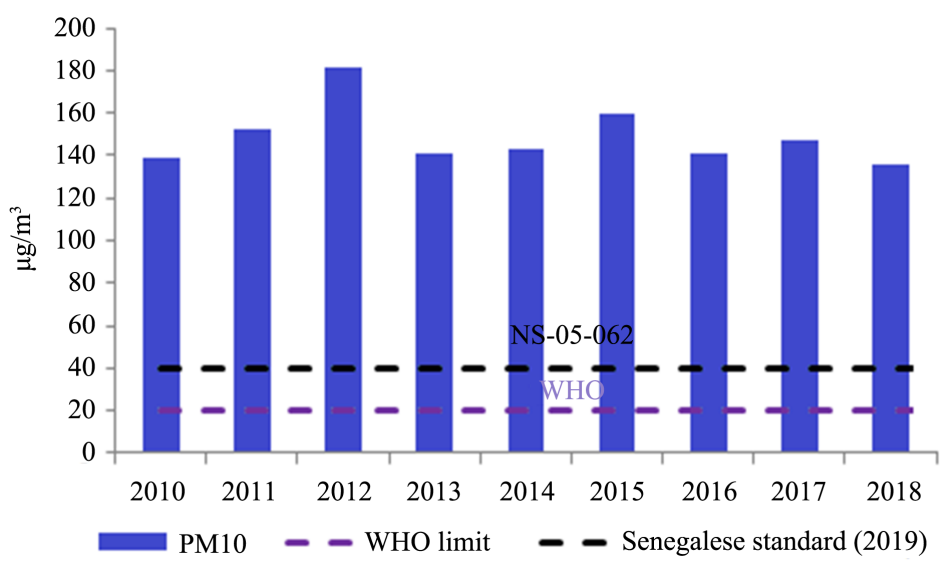

Figure 5. Annual changes in mean $\mathrm{PM}_{10}$ concentrations from 2010 to 2018 (Source: CGQA).

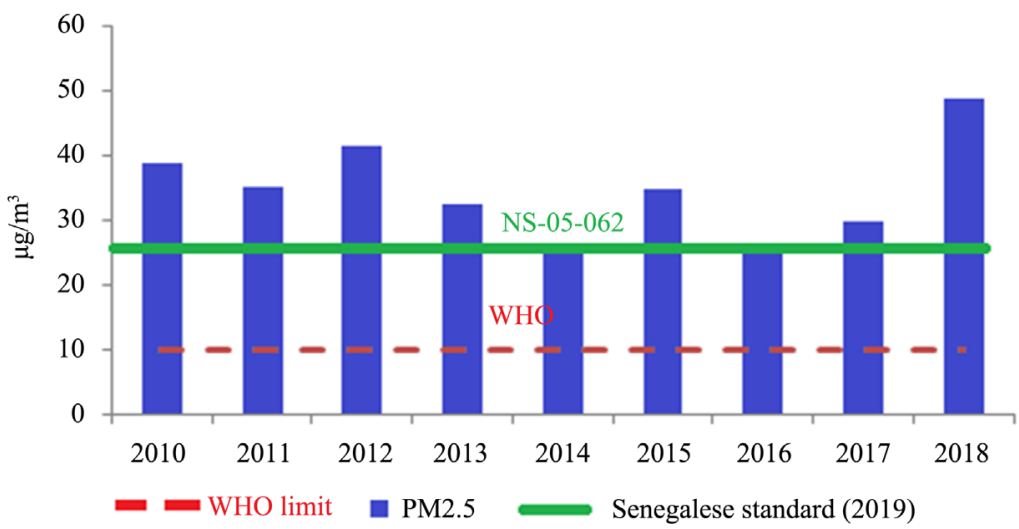

Figure 6. Annual changes in mean $\mathrm{PM}_{2.5}$ concentrations from 2010 to 2018 (Source: 
CGQA).

Furthermore, there is a correlation between pollution episodes and the increase in particle concentrations (Figures 2-4). So particles seem to be the main cause of pollution episodes in Dakar. A study on the degradation of air quality in the first trimester of 2015 showed a correspondence between the increase in the concentrations of $\mathrm{PM}_{10}$ and $\mathrm{PM}_{2.5}$, the peaks of which occurred at the same periods [17]. These particles come mainly from desert dust $\left(\mathrm{PM}_{10}\right)$ and the transport sector $\left(\mathrm{PM}_{2.5}\right)$.

In the dry period, between November and April, most cities located in the Sahelian zone are confronted, in addition to anthropogenic pollution, to dry winds from the North East (Harmattan). During this period, several towns in the region experience very high levels of dust particles [18]. Dust is lifted into the atmosphere by storm events that can move large amounts of particles into the upper troposphere, where they are then carried over long distances by tropospheric winds [19]. The analysis of these desert aerosols shows a very large variability of the particles in terms of size, most of which have a diameter between 1 and 10 $\mu \mathrm{m}$. This dust has a huge impact on atmospheric visibility, affects the intensity of solar radiation and is a source of several diseases such as meningitis [20]. A study carried out particularly in Fann-Hospital in the Dakar region showed that the air samples taken during dust episodes contained living organisms (bacteria, fungi, viruses), including opportunistic human pathogens (Penicillium, Aspergillus) that can cause respiratory diseases [21].

Figure 5 shows a little variation in average concentrations of $\mathrm{PM}_{10}$ from year to year. Between 2010 and 2012, the annual averages varied from $120 \mu \mathrm{g} \cdot \mathrm{m}^{-3}$ to reach a maximum level in 2012 at $180 \mu \mathrm{g} \cdot \mathrm{m}^{-3}$, then decreased in 2013 to 140 $\mu \mathrm{g} \cdot \mathrm{m}^{-3}$. From 2014 we have an alternation between a decrease and an increase in the concentration of $\mathrm{PM}_{10}$. Between 2014 and 2018, the annual average concentrations decreased, going from $160 \mu \mathrm{g} \cdot \mathrm{m}^{-3}$ to $135 \mu \mathrm{g} \cdot \mathrm{m}^{-3}$. The measured concentration values are within the range of concentrations observed in most Sahelian regions ( 119 to $227 \mu \mathrm{g} \cdot \mathrm{m}^{-3}$ ). Figure 6 shows that the annual average concentrations of $\mathrm{PM}_{2.5}$ vary between 25 and $48 \mu \mathrm{g} \cdot \mathrm{m}^{-3}$ during the period from 2010 to 2018. Between 2010 and 2015 there is an alternation from one year to another with an increase and decrease in $\mathrm{PM}_{2.5}$ concentration. From 2016 to 2018, the concentration of $\mathrm{PM}_{2.5}$ almost doubled, going from 25 to $48 \mu \mathrm{g} \cdot \mathrm{m}^{-3}$. Air emissions of $\mathrm{PM}_{10}$ and $\mathrm{PM}_{2.5}$ particles in Dakar are produced mainly by anthropogenic activities and represent $61 \%-68 \%$ of total emissions [22]. In fact, resuspension dust contributes $13 \%-23 \%$, the source linked to traffic $32 \%-42 \%$, the marine source $15 \%-21 \%$, the source associated with the production of cement and the construction sector $13 \%-18 \%$, the source of fuel combustion linked to port activities $5 \%-13 \%$ and wear of vehicle brakes 5\% - 13\% [22]. The large part of road traffic is linked to the fact that the vehicle fleet is constantly increasing.

In addition, road transport emits significant amounts of $\mathrm{PM}_{2.5}$. In fact, the vehicle fleet, made up mainly of imported used vehicles, is often dilapidated and outdated. The obsolescence of vehicles leads to overconsumption of fuels (gaso- 
line, diesel) which is accompanied by a high concentration of pollutants and deterioration of air quality in cities [23]. $\mathrm{PM}_{2.5}$, mainly emitted by diesel-powered vehicles, is the most dangerous because they cross the pulmonary barrier and enter the bloodstream.

\section{Conclusion}

Despite the significant progress recorded by the government of Senegal since 2003 with the implementation of the NS 05-062 standard and recently with the creation of a monitoring system (in 2010), the air people breathe is not always of good quality in the city of Dakar. In fact, the city is confronted throughout the year with particulate pollution with worrying levels far exceeding the limit values. In addition to particulate pollution, some types of pollution such as nitrogen dioxide and tropospheric ozone are also of great concern. These pollutants are dangerous for health, sometimes even at low doses. The mechanisms of their formation and their behaviour are complex. They come from road transport, industry, biomass fires and surface dumps. This work allows realizing the importance of monitoring air quality. It also helps the authorities to put in place strategies to drastically reduce air pollution. Dakar residents, informed day by day about the quality of the air they breathe, expect a lot from the action of the public authorities, but they are also one of the keys to improving the situation. This necessarily involves a renewal of the vehicle fleet, that is the gradual replacement of old transport vehicles (Car-rapides, ndiaga-ndiaye, clandos) by modern buses and taxis (vehicles with less polluting technologies). The government of Senegal is committed to reducing the negative externalities of transport through the development of public transport systems such as the regional express train (TER) and the rapid transit bus project (BRT). In the industrial sector, the public authorities should strengthen regulatory requirements by imposing heavy taxes on polluting activities to encourage manufacturers to use fewer polluting technologies.

\section{Conflicts of Interest}

The authors declare no conflicts of interest regarding the publication of this paper.

\section{References}

[1] Tchanche, B. (2019) A View of Road Transport in Africa. African Journal of Environmental Science and Technology, 13, 296-302. https://doi.org/10.5897/AJEST2018.2575

[2] Tchanche, B. (2021) Dynamics of Greenhouse Gas (GHG) Emissions in the Transportation Sector of Senegal. Earth, 2, 1-15. https://doi.org/10.3390/earth2010001

[3] Tchanche, B. (2018) Analyse du système énergétique du Sénégal. Revue des Energies Renouvelables, 21, 73-88.

[4] Tchanche, B. and Diaw, I. (2017) Analyse énergétique du secteur des transports du 
Sénégal. Proceedings. of 1ere Conférence Ouest Africaine des Energies Renouvelables, 28 June-2 July 2017, Saint-Louis, Sénégal.

[5] Sivertsen, B., Ndiaye, A. and Diop, M. (2010) Air Quality Monitoring in Dakar.

[6] ASN (2003) Pollution atmosphérique-Norme de rejets NS 05-062. Association Sénégalaise de Normalisation, Octobre, Senegal, 22 p.

[7] Banque Mondiale (1998) Etudes sur la qualité de l'air en milieu urbain: cas de Dakar et de Ouagadougou. Rapports finaux, Document de travail SSATP N41, 228 p.

[8] Cabral, M., et al. (2012) Impact du recyclage des batteries de véhicules sur la santé humaine et l'Environnement: Etude pilote effectuée sur des femmes de Colobane et des mécaniciens de Médina. Annales de toxicologie analytique, 24, 1-7. https://doi.org/10.1051/ata/2012003

[9] Demay, C. (2011) La pollution de l'air à Dakar, Mémoire de Master. Université de Bourgogne, $71 \mathrm{p}$.

[10] Dieme, D., Cabral, M., Verdin, A. and Diouf, A. (2011) Caractérisation physico-chimique et effets cytotoxiques de particules atmosphériques PM2.5 de la ville de Dakar (Sénégal). Annales de toxicologie analytique, 23, 157-167. https://doi.org/10.1051/ata/2011132

[11] Doumbia, E.H.T., et al. (2012) Real Time Black Carbon Measurements in West and Central Africa Urban Sites Real Time Black Carbon Measurements in West and Central Africa Urban Sites. Atmospheric Environment, 54, 529-537. https://doi.org/10.1016/j.atmosenv.2012.02.005

[12] Fall, M. et al. (2008) Réponse toxicologique d'une culture organotypique de tissu pulmonaire exposée à des gaz d'échappement issus d'un moteur à combustion. Environnement, Risques \& Santé, 7, 123-129.

[13] Ndong, A.B., et al. (2019) Individual Exposure Level Following Indoor and Outdoor Air Pollution Exposure in Dakar (Senegal). Environmental Pollution, 248, 397-407. https://doi.org/10.1016/j.envpol.2019.02.042

[14] Val, S., et al. (2013) Physico-Chemical Characterization of African Urban Aerosols (Bamako in Mali and Dakar in Senegal ) and Their Toxic Effects in Human Bronchial Epithelial Cells: Description of a Worrying Situation, Particle and Fibre Toxicology, 10, Article No. 10. https://doi.org/10.1186/1743-8977-10-10

[15] OMS (2006) Lignes directrices OMS relatives à la qualité de l'air: Particules, ozone, dioxyde d'azote et dioxyde de soufre.

[16] Nana, B., Sanogo, O., Savadogo, P.W., Daho, T., Bouda, M. and Koulidiati, J. (2012) Air Quality Study in Urban Centers: Case Study of Ouagadougou, Burkina Faso, FUTY Journal of the Environment, 7, Article No. 1. https://doi.org/10.4314/fje.v7i1.1

[17] Diokhane, A.M., Sagna, P., Diop, C., Sambou, P.C. and Dioh, A.J.M.N. (2016) Importance de la dégradation de lla qualité de l'air à Dakar au premier trimestre 2015: Eléménts d'explication. XXIXe Colloque de P Association Internationale de Climatologie, Lausanne-Besançon.

[18] Afeti, G.M. and Resch, F.J. (2000) Physical Characteristics of Saharan Dust Near the Gulf of Guinea. Atmospheric Environment, 34, 1273-1279. https://doi.org/10.1016/S1352-2310(99)00296-4

[19] Konare, A., et al. (2008) A Regional Climate Modeling Study of the Effect of Desert Dust on the West African Monsoon. Journal of Geophysical Research: Atmospheres, 113, Article ID: D12206. https://doi.org/10.1029/2007JD009322

[20] Nébon B., et al. (2019) Intra-Seasonal and Annual Variation of Aerosols and Their 
Radiative Impact in the Sahelian Zone of Burkina Faso. Atmospheric and Climate Sciences, 9, 62-74. https://doi.org/10.4236/acs.2019.91004

[21] Marone, A., et al. (2018) Caractérisation des champignons en aérosol à partir des événements de poussières à Dakar, Sénégal, Afrique de l'Ouest. Afrique Science, 14, 304-315. http://www.afriquescience.net.

[22] Doumbia, E.H.T. (2012) Caractérisation physico-chimique de la pollution atmosphérique urbaine en Afrique de l'Ouest et étude d'impact sur la santé. Université Paul Sabatier-Toulouse III, 243 p.

[23] Liousse, C. and Galy-Lacaux, C. (2010) Pollution urbaine en Afrique de l'Ouest Urban pollution in West Africa. La Météorologie, 71, 45-49.

https://doi.org/10.4267/2042/37377 